\title{
Hubungan Pengetahuan dan Karakteristik Ibu Baduta dengan Pemberian Asi Eksklusif di Wilayah Kelurahan Meruya Utara Tahun 2020
}

\author{
Septia Nur Rahma, Dwi Mutia Wenny, Agustina, Putri Permatasari \\ Program Studi Kesehatan Masyarakat Program Sarjana, Fakultas Ilmu Kesehatan
}

\begin{abstract}
Abstrak
Latar Belakang: Data WHO menunjukkan bahwa bayi 0 sampai dengan 6 bulan di dunia yang mendapatkan ASI Eksklusif hanyalah sebesar 38\%. Pemberian ASI eksklusif dipengaruhi oleh beberapa hal, termasuk faktor sosio demografi ibu seperti usia, pendidikan, pengetahuan, dan pekerjaan ibu. Di Meruya Utara, perilaku ibu untuk melaksanakan ASI Eksklusif masih dipengaruhi dengan mitos atau tabu yang berpengaruh pada kurangnya pemahaman ibu sehingga menghambat pemberian ASI. Studi ini bertujuan untuk mengetahui hubungan pengetahuan dan karakteristik ibu baduta di Wilayah Kelurahan Meruya Utara dengan pemberian ASI Eksklusif.

Metode: Studi ini ialah studi kuantitatif dengan desain studi Cross Sectional. Sebanyak 194 ibu dengan baduta di wilayah Kelurahan Meruya Utara menjadi sampel studi yang diperoleh menggunakan metode purposive sampling. Studi ini menggunakan pengetahuan dan karakteristik ibu berupa usia, pendidikan, status pekerjaan, dan tingkat penghasilan sebagai variabel independen. Sementara variabel dependennya adalah ASI Eksklusif. Uji statistik dilakukan menggunakan uji Chi-Square dengan tingkat signifikansi 0,05.

Hasil: Hasil studi menunjukkan 46,9\% ibu dengan baduta telah memberikan ASI Eksklusif. Hasil analisis bivariat menujukkan adanya hubungan yang signifikan antara pengetahuan ibu (p-value =0,030), usia ibu ( $p$ value $=0,022)$, dan tingkat pendidikan ibu (p-value =0,017) dengan pemberian ASI Eksklusif. Sedangkan status pekerjaan ( $p$-value $=0,250$ ) dan tingkat penghasilan ( $p$-value $=0,673$ ) tidak memiliki hubungan signifikan.

Kesimpulan: Ibu dengan baduta disarankan untuk rutin mengakses informasi kesehatan secara mandiri melalui internet guna memperoleh informasi terkait Kesehatan Ibu dan Anak sebagai upaya untuk meningkatkan derajat kesehatan masyarakat.
\end{abstract}

Kata Kunci: ASI Eksklusif, Pendidikan, Pengetahuan, Usia Ibu Baduta,

\section{The Relationship of Mother's Knowledge and Characteristics With The Exclusive Breastfeeding in The Area of Meruya Utara Village 2020}

\begin{abstract}
Background: There are only 38\% of infants aged 0 to 6 months worldwide who are exclusively breastfed. Various kinds of things that can influence mothers in giving exclusive breastfeeding are mother's age, education, knowledge, and occupation. In North Meruya, the behavior of exclusive breastfeeding is still influenced by myths or taboos that affect the lack of understanding of mothers about exclusive breastfeeding. The purpose of this study was to analyze the relationship between knowledge and characteristics of mothers with exclusive breastfeeding in the North Meruya Village.

Methods: This was a cross sectional study. The sample of this study was 194 mothers who have children aged 624 months in North Meruya Village. The sampling technique was purposive sampling. This study uses knowledge and characteristics of mothers such as age, education, employment status, and income level as independent variables and exclusive breastfeeding as the dependent variable. The statistical test used was the Chi-Square test with a significance level of 0.05 .

Result: The results confirmed that 46.9\% mothers had given an exclusive breastfeed. The bivariate analysis confirmed that there has been significant relationship among mother's knowledge ( $p$-value $=0.030)$, mother's age ( $p$-value $=0.022)$, and mother's education level ( $p$-value $=0.017)$ with the giving of exclusive breastfeed. Meanwhile, the variables that did not have significant relationship had been job status ( $p$-value $=0.250)$ and profits level ( $p$-value $=0.673$ ).

Conclusion: Mothers who have children aged 6-24 months are encouraged to regularly access health information independently through the internet to obtain information related to Maternal and Child Health as an effort to improve public health status.
\end{abstract}

Keywords: Exclusive Breastfeeding, Education, Knowledge, Mother's Age

Korespondensi: Septia Nur Rahma

Email: septianurrahma@upnvj.ac.id 


\section{PENDAHULUAN}

Dalam dua tahun pertama kehidupan anak, terdapat waktu krusial yang sangat berpengaruh bagi kehidupan mereka di masa mendatang. Tubuh dan otak anak tumbuh serta berkembang pesat di dalam tahapan ini, sehingga kecukupan gizi penting untuk diperhatikan. gizi yang berkualitas perlu diberikan untuk membentuk potensi anak secara fisik, psikis, dan intelektual. Cara terbaik untuk memenuhi gizi tersebut ialah dengan 6 bulan awal ibu menyusui bayi sepenuhnya ${ }^{1}$

WHO merekomendasikan secara global bahwa bayi harus disusui sesegera mungkin setelah lahir, dan kemudian terus memberikan hanya ASI selama 6 bulan, serta tidak mengasihkan makanan tambahan apa pun ${ }^{2}$.

Berdasarkan data WHO, di seluruh dunia, bayi berusia antara 0 dan 6 bulan hanya $38 \%$ saja yang menerima ASI Eksklusif ${ }^{3}$. Untuk Asia Tenggara, dari hasil Multiple Indicator Cluster Survey (MICS) pada 20082012 didapatkan hasil bahwa Indonesia memiliki cakupan ASI Eksklusif terbesar ketiga dengan persentase $42 \%$ dimana masih di bawah rata-rata ${ }^{4}$. Data Profil Kesehatan DKI Jakarta 2018 menunjukkan bahwa cakupan pemberian ASI Jakarta Barat berada di posisi terendah dengan persentasenya sebesar $60,5 \%$ 5 .

Satu di antara penyebab kurangnya cakupan pemberian ASI Eksklusif pada bayi ialah pengetahuan seorang Ibu mengenai manfaat dan kandungan dari diperolehnya ASI saja oleh bayi usia 0-6 bulan, tentu saja pengetahuan seseorang dipengaruhi oleh tingkat pendidikan yang ia tempuh. Selain itu, status pekerjaan juga bisa dijadikan faktor masih rendahnya ibu yang memberikan ASI eksklusif. Ibu yang memiliki bekerja aktif cenderung memiliki hambatan dalam memberikan ASI eksklusif akibat masa cuti melahirkan yang berakhir tanpa menunggu usia bayi menginjak bulan keenam ${ }^{6}$. Tingkat penghasilan di dalam keluarga juga dapat menjadi satu di antara penyebab diberikan atau tidaknya ASI Eksklusif.

Untuk mengetahui urgensi pada wilayah Kelurahan Meruya Utara terkait pemberian ASI Eksklusif, penulis melakukan wawancara singkat di wilayah tersebut kepada sejumlah Ketua Posyandu dan Koordinator Dasawisma di Kelurahan Meruya Utara. Dari hasil wawancara tersebut didapatkan jawaban bahwa masih adanya berbagai penyebab pengaruh terhambatnya ibu dalam memberikan ASI eksklusif pada usia 0 sampai 6 bulan, antaranya ialah berdasarkan pengetahuan yang dimiliki ibu.

Cakupan pemberian ASI Eksklusif yang rendah ini memberikan dampak buruk pada perekonomian secara nasional dan kualitas hidup anak Indonesia sebagai generasi penerus 7. Beberapa studi juga mengemukakan bahwa masalah pemberian ASI eksklusif ini berkaitan erat dengan risiko terhadap stunting ${ }^{8}$.

Penelitian ini bertujuan untuk mengetahui hubungan pengetahuan dan karakteristik ibu dengan pemberian ASI Eksklusif di Kelurahan Meruya Utara Tahun 2020.

\section{METODE}

Studi ini merupakan dtudi kuantitatif dengan design studi cross sectional. Responden penelitian merupakan ibu dengan baduta, berjumlah 194 yang ditentukan menggunakan teknik purposive sampling. Responden dipilih berdasarkan kriteria inklusi yaitu ibu baduta yang bertempat tinggal di wilayah Kelurahan Meruya Utara, memiliki anak berusia antara 6-24 bulan, dan menyatakan siap dijadikan responden. Sedangkan responden yang tidak dipilih ditentukan berdasarkan kriteria eksklusi yaitu ibu baduta berada di lokasi lain (isolasi, pulang kampung, dan lain-lain) saat penelitian berlangsung dan tidak bersedia dijadikan respoden.

Pengambilan data penelitian ini menggunakan kuesioner elektronik yang telah dilakukan uji validitas dan reliabilitas. Kuesioner berisi pertanyaan mengenai karakteristik responden, pengetahuan mengenai ASI, dan pemberian ASI Eksklusif. Sebelum mengisi kuesioner, responden mengisi informed consent sebagai tanda persetujuan keterlibatan dalam peneltian ini.

Analisis data dilakukan secara univariat dan bivariat menggunakan uji statistik chisquare dengan derajat kemaknaan $(\alpha)=0,05$. 


\section{HASIL}

1. Analisis Univariat

Tabel 1 Distribusi Frekuensi Pemberian ASI Eksklusif, Pengetahuan, dan Karakteristik Responden

\begin{tabular}{lcc}
\hline \multicolumn{1}{c}{ Variabel } & Frekuensi & Persentase (\%) \\
\hline Pemberian ASI Eksklusif & 103 & 53,1 \\
Tidak Eksklusif & 91 & 46,9 \\
Eksklusif & & \\
Pengetahuan & 3 & 1,5 \\
Kurang & 39 & 20,1 \\
Cukup & 152 & 78,4 \\
Baik & & \\
Usia & 38 & 19,6 \\
$<20$ tahun atau >35tahun & 156 & 80,4 \\
20-35 tahun & & \\
& & \\
Pendidikan & 13 & 6,7 \\
SD & 40 & 20,6 \\
SMP & 103 & 53,1 \\
SMA & 38 & 19,6 \\
Perguruan Tinggi & & \\
Tingkat Pendidikan & 53 & 27,3 \\
Rendah & 141 & 72,7 \\
Tinggi & & \\
Status Pekerjaan & 39 & 20,1 \\
Bekerja & 155 & 79,9 \\
Tidak Bekerja & & \\
Tingkat Penghasilan & 79 & 59,7 \\
$\geq$ UMR DKI Jakarta & 115 & \\
< UMR DKI Jakarta & & \\
\hline
\end{tabular}

Diketahui dari 194 responden, mayoritas responden tidak memberikan anaknya ASI secara eksklusif 53,1\%, kebanyakan responden berpengetahuan baik 78,4\%, responden mayoritas berusia 20-35 tahun $80,4 \%$, pendidikan terakhir responden kebanyakan ialah setingkat
SMA 53,1\%, tingkat pendidikan dari responden sebagian besar tinggi 72,7\%, sebagian besar responden tidak bekerja $79,7 \%$, dan mayoritas responden memiliki tingkat penghasilan keluarga kurang UMR Provinsi DKI Jakarta 59,3\%. 
memberikan ASI secara eksklusif (44,5\%) dan 22 responden yang bekerja telah memberikan ASI secara eksklusif (56,4\%). Lalu terdapat 52 responden dengan penghasilan keluarga di bawah UMR Provinsi DKI Jakarta telah memberikan ASI secara eksklusif (45,2\%) dan 39 responden dengan penghasilan keluarga tepat atau di atas UMR Provinsi DKI Jakarta telah memberikan ASI secara eksklusif (49,4\%).

Hubungan karakteristik ibu dengan pemberian ASI Eksklusif diperoleh usia ibu dengan $p$-value $<\alpha(\mathrm{p}=0,022)$, variabel tingkat pendidikan ibu dengan $p$-value $<\alpha$ $(\mathrm{p}=0,017)$, status pekerjaan ibu dengan $p$ value $>\alpha \quad(\mathrm{p}=0,250)$, tingkat penghasilan keluarga dengan $p$-value $>\alpha \quad(\mathrm{p}=0,673)$. Dengan demikian, didapatkan simpulan yaitu terdapatnya hubungan bermakna antara usia ibu dan tingkat pendidikan ibu dengan pemberian ASI Eksklusif. Sementara itu, status pekerjaan ibu dan tingkat penghasilan keluarga tidak hubungan bermakna dengan pemberian ASI Eksklusif.

\section{PEMBAHASAN}

Pemberian ASI Eksklusif oleh Ibu Baduta di Wilayah Kelurahan Meruya Utara

Pemberian ASI Ekslusif ialah satu di antara hal yang perlu diupayakan guna diperolehnya tumbuh kembang anak yang optimal serta terlindungi dari penyakitpenyakit infeksi di kemudian hari ${ }^{8}$. Lebih dari separuh responden dalam penelitian ini ternyata tidak memberikan ASI eksklusif. Penelitian ini memperoleh hasil yang selaras pada hasil penelitian Djamil, Hermawan, dan Setiarini bahwa sebagian besar responden juga tidak memberikan ASI scara eksklusif ${ }^{9}$. Ini diduga karena kurangnya wawasan serta informasi terkait dengan pentingnya ASI eksklusif, usia dengan kemampuan reproduksi yang telah menurun, serta pendidikan yang cenderung rendah. Kehidupan sosial budaya juga diduga dapat mempengaruhi ibu untuk tidak memberikan ASI Eksklusif. Perilaku dibentuk oleh kebiasaan yang diwarnai dengan sosial budaya. Banyaknya kepercayaan dalam budaya mengenai tabu dalam menyusui, salah satunya adalah pantangan bagi ibu menyusui untuk mengkonsumsi makanan amis seperti telur, ayam, dan ikan serta pembuangan kolostrum karena dianggap sebagai cairan yang kotor, hal tersebut dapat mempengaruhi seseorang untuk tidak memberikan ASI secara eksklusif ${ }^{10}$.

\section{Hubungan Antara Pengetahuan Ibu} dengan Pemberian ASI Eksklusif

Mayoritas responden memiliki pengetahuan baik. Pengetahuan ibu dengan pemberian ASI Eksklusif dinyatakan berhubungan bermakna. Sebuah studi juga menunjukkan bahwa semakin banyaknya pengetahuan baik yang dimiliki seorang ibu mengenai ASI akan berpengaruh pada cara berpikir serta cara ibu bersikap yang pada akhirnya muncul perilaku atau tindakan yang tepat berupa diberikannya ASI secara eksklusif ${ }^{11}$. Pengetahuan ialah satu di antara ranah esensial dalam membentuk perilaku. Perilaku seseorang jika didasari pengetahuan dan kesadaran yang baik cenderung akan terus konsisten dijakalani. Seseorang dengan pengetahuan yang baik lebih mudah dalam mengubah perilaku termasuk tindakan pemberian ASI Eksklusif ${ }^{12}$.

\section{Hubungan Antara Usia Ibu dengan Pemberian ASI Eksklusif}

Sebagian besar ibu berusia 20-35 tahun telah memberikan ASI secara 
eksklusif. Selain itu, hasil uji statistik menunjukkan usia ibu berhubungan bermakna dengan pemberian ASI Eksklusif. Kebermaknaan hubungan usia ibu dengan pemberian ASI Eksklusif ini selaras dengan penelitian yang menyatakan ibu dalam rentang usia 20 hingga 35 tahun berada pada fase terbaik secara kesehatan dan kematangan fungsi reproduksi yang pada umumnya mampu menunjang ibu dalam memberikan ASI secara eksklusif. Sementara itu, ibu dengan usia yang sudah melebihi angka 35 tahun dianggap berisiko sekalipun anaknya berstatus gizi baik, sebab organ pada tubuh ibu khususnya yang berkaitan dengan fungsi reproduksi telah melemah serta berkurang produktivitasnya, selanjutnya risiko yang diwariskan kepada anak pun rentan terjadi 13. Ibu dengan rentang usia 20 hingga 35 tahun telah memasuki "masa dewasa" secara emosional sehingga masalahmasalah dapat dihadapi dengan baik terutama saat mengalami masa hamil, bersalin, nifas, dan mengasuh bayi. Sedangkan ibu dengan usia sebelum 20 tahun pada umumnya belum cukup paham dan secara fisik juga sosial belum siap melewati masa hamil, proses melahirkan baik secara normal maupun operasi, serta selanjutnya merawat bayi setelah keluar dari rahim ibu. Sedengkan ibu berusia lebih dari 35 tahun telah mengalami pengurangan hormon yang dihasilkan tubuh, hingga menyebabkan performa tubuh dalam menghasilkan ASI pun turut menurun ${ }^{14}$.

\section{Hubungan Antara Tingkat Pendidikan Ibu dengan Pemberian ASI Eksklusif}

Adanya hubungan bermakna tingkat pendidikan ibu dengan pemberian ASI eksklusif, responden berpendidikan tinggi cenderung memberikan ASI secara eksklusif. Studi lain juga menyatakan semakin tinggi tingkat pendidikan ibu maka akan memunculkan motivasi yang tinggi pula untuk memberikan ASI secara eksklusif ${ }^{11}$. Pendidikan ialah satu di antara faktor predisposisi dalam memudahkan seorang ibu ketika ia berupaya meningkatkan kemauannya untuk memberikan ASI secara eksklusif. Pendidikan yang telah ibu tempuh akan berpengaruh terhadap kualitas wawasan dan pengetahuan ibu serta cara ibu bersikap. Oleh karenanya, ibu yang menempuh pendidikan tinggi akan lebih mampu menerima pemikiran yang mutakhir dan ter-update mengenai pentingnya serta cara yang tepat dalam pemberian ASI Eksklusif. Artinya, tingginya tingkatan pendidikan ibu berperan dalam menyukseskan program ASI Eksklusif ${ }^{15}$.

\section{Hubungan Antara Status Pekerjaan Ibu dengan Pemberian ASI Eksklusif}

Tidak terdapat kebermaknaan hubungan status pekerjaan ibu dengan pemberian ASI Eksklusif. Sebagian besar ibu yang bekerja ternyata tetap dapat memberikan ASI secara eksklusif. Studi lain juga yang menyatakan pekerjaan ibu sehari-hari berdampak pada terbatasnya waktu yang senggang untuk ibu memberikan ASI secara eksklusif. Ibu dengan keseharian yang memiliki pekerjaan cenderung menggantikan air susu ibu dengan susu formula saat ia aktif kembali pada pekerjaanya, meskipun seharusnya apabila pengetahuan yang ibu punya tepat mengenai pentingnya ASI Eksklusif disertai dukungan seluruh pihak dalam lingkup tempat kerja, ibu akan konsisten menyusui atau mempersiapkan ASI ${ }^{13}$. Kini ibu yang dalam kesehariannya diharuskan beraktifitas di luar rumah, termasuk bekerja tetap bisa memberikan ASI Eksklusif sebab pemerintah telah 
mengharuskan seluruh lapisan masyarakat memberikan dukungan positif agar ibu dapat terpenuhi haknya dalam memberikan ASI. Tempat bekerja khususnya perkantoran diwajibkan untuk menyediakan ruang laktasi sehingga pegawai yang merupakan ibu menyusui dapat selalu mengasihi anaknya di 6 bulan pertama dengan cara memerah atau menyusui selama jam kerja ${ }^{16}$.

Hubungan Antara Tingkat Penghasilan Keluarga dengan Pemberian ASI Eksklusif

Mayoritas responden dengan penghasilan keluarga $<$ UMR DKI Jakarta tidak memberikan ASI Eksklusif kepada anaknya. Tingkat penghasilan keluarga tidak berhubungan bermakna dengan pemberian ASI Eksklusif. Sebuah studi mengemukakan hal serupa, bahwa jika keluarga memiliki tingkat penghasilan yang rendah, maka seorang ibu pada umumnya turut mencari nafkah untuk menopang kebutuhan ekonomi keluarganya. Kondisi ibu yang terpaksa harus turut bekerja berdampak pada tidak adanya kesempatan atau waktu luang untuk ibu memberikan bayinya ASI secara eksklusif 17. Rendahnya penghasilan keluarga meningkatkan peluang untuk ibu memberikan ASI secara eksklusif, tetapi tetap ada kemungkinan bahwa keluarga dengan tingkat penghasilan yang rendah justru tidak pula mempraktikkan pemberian ASI Eksklusif. Satu diantara faktornya ialah kurangnya kemampuan untuk memenuhi kebutuhan gizi ibu selama masa kehamilan yang dapat berdampak pada proses persalinan dan seterusnya, seperti terhambatnya keinginan ibu untuk menyusui di awal kelahiran ataupun sempat menyusui saat awal bayi lahir tetapi tidak dapat meneruskannya dikarenakan ASI yang dihasilkan kurang kuantitasnya ${ }^{18}$.

\section{KESIMPULAN}

Pengetahuan ibu, usia ibu, dan tingkat Pendidikan ibu berhubungan dengan. pemberian ASI Eksklusif. Sedangkan status pekerjaan ibu dan tingkat penghasilan keluarga tidak berhubungan dengan pemberian ASI Eksklusif.

\section{SARAN}

Diharapkan ibu dengan baduta yaitu rutin mengunjungi Posyandu atau menghubungi kader kesehatan untuk berkonsultasi terkait pantauan tumbuh kembang anak, selain itu dapat pula memperoleh informasi melalui internet dengan memperhatikan sumber yang kredibel. Kemudian saran bagi Puskesmas Kelurahan Meruya Utara yaitu menginformasikan edukasi terkait ASI Eksklusif saat ibu berkunjung ke Posyandu atau membuat grup secara daring sebagai media untuk bertukar informasi kesehatan khususnya mengenai kesehatan ibu dan anak. Selanjutnya saran bagi peneliti selanjutnya yaitu menambahkan variabel dukungan suami atau pengaruh budaya, dikarenakan dua hal tersebut dapat berpengaruh pula dalam pemberian ASI secara eksklusif.

\section{DAFTAR PUSTAKA}

1. Kadir NA. Menelusuri Akar Masalah Rendahnya Persentase Pemberian ASI Eksklusif di Indonesia. J Al Hikmah. 2014;15(1):106-18.

2. Maulida H, Afifah E, Pitta Sari D. Tingkat Ekonomi dan Motivasi Ibu dalam Pemberian ASI Eksklusif pada Bayi Usia 0-6 Bulan di Bidan 
Praktek Swasta (BPS) Ummi Latifah Argomulyo, Sedayu Yogyakarta. J Ners dan Kebidanan Indones. 2016;3(2):116.

3. WHO, UNICEF. Global Nutrion Target 2025: Breastfeeding Policy Brief. Switzerland; 2014.

4. Walters D, Horton S, Siregar AYM, Pitriyan P, Hajeebhoy N, Mathisen $\mathrm{R}$, et al. The cost of not breastfeeding in Southeast Asia. Health Policy Plan. Oktober 2016;31(8):1107-16.

5. Dinkes Provinsi DKI Jakarta. Profil Kesehatan Provinsi DKI Jakarta Tahun 2018. Jakarta; 2018.

6. Bahriyah F, Jaelani AK, Putri M. Hubungan Pekerjaan Ibu Terhadap Pemberian Asi Eksklusif Pada Bayi Di Wilayah Kerja Puskesmas Sipayung. J Endur. 2017;2(2):113.

7. IDAI. Dampak dari Tidak Menyusui di Indonesia. idai.or.id. 2016.

8. Karima UQ, Herbawani CK, Puspita ID. Pengaruh Praktik Pemberian ASI Terhadap Risiko Stunting di Indonesia : Studi Literatur. 2021; (November 2020).

9. Djamil A, Hermawan NSA, Setiarini N. Hubungan Pelaksanaan Manajemen Laktasi oleh Petugas Kesehatan terhadap ASI Eksklusif pada Ibu Menyusui. J Kesehat. 2018;9(1):113.

10. Hidayati H. Hubungan Sosial Budaya dengan Keberhasilan Pemberian ASI Eksklusif pada Ibu Menyusui di Posyandu Wilayah Desa Srigading Sanden Bantul Yogyakarta. Stikkes 'Aisyiyah. Stikes 'Aisyiyah Yogyakarta; 2013.
11. Rachmaniah N. Hubungan Tingkat Pengetahuan Ibu Tentang ASI dengan Tindakan ASI Eksklusif. Universitas Muhammadiyah Surakarta; 2014.

12. Soekidjo Notoatmodjo. Kesehatan Masyarakat Ilmu dan Seni. Edisi Revi. Jakarta: Rineka Cipta; 2011.

13. Atabik A. Faktor Ibu yang Berhubungan dengan Praktik Pemberian ASI EKslusif di Wilayah Kerja Puskesmas Pamotan. Unnes J Public Heal. 2014;3(1):1-10.

14. Nurbayanti ES. Karakteristik Ibu yang Berhubungan dengan Pemberian ASI Eksklusif di Puskesmas Temon II Kulon Progo Yogyakarta. Univ Aisyiyah Yogyakarta. 2016;

15. Pangestika E. Hubungan Tingkat Pendidikan Ibu dengan Praktik Pemberian ASI Eksklusif pada Ibu yang Melahirkan di RSUD Wates Kulon Progo. STIKES Jenderal Achmad Yani Yogyakarta; 2016.

16. Jauhari I, Fitriani R, Bustami. Perlindungan Hak Anak terhadap Pemberian Air Susu Ibu (ASI) . Yogyakarta: Penerbit Deepublish; 2018.

17. Fadlliyyah UR. Determinan Faktor Yang Berpengaruh Pada Pemberian Asi Eksklusif Di Indonesia. Ikesma. 2019;15(1):51.

18. Pasaribu P, Mayulu N, Malonda NSH. Hubungan Status Sosial Ekonomi Orangtua Dengan Pemberian Asi Eksklusif Di Kota Manado. Kesmas. 2017;6(3):1-9. 